\title{
Komplikasjoner etter kronisk ryggmargsskade
}

\author{
Sammendrag \\ Bakgrunn. En ryggmargsskade forand- \\ rer kroppsbygning og metabolisme \\ over tid. Hovedformålet med denne \\ artikkelen er å gi en oversikt over hva \\ man vet om slike forandringer i dag og \\ konsekvensene av disse i den kroniske \\ fasen lang tid etter den akutte skaden.

\section{Materiale og metode. Artikkelen er basert på egne publiserte data, klinisk erfaring og ikke-systematiske $s ø k$ i databasen PubMed.}

Resultater. Hos individer med ryggmargsskade er det dokumentert redusert bein- og muskelmasse, forandret muskelfibersammensetning, kraftig $ø$ kning av kroppsfett, nedsatt følsomhet for insulin og leptin og økt aktivitet i inflammatoriske signalkjeder. Forandringer er videre påvist både i hemostasemekanismer og immunapparatet.

Fortolkning. Endringer i metabolisme og i hormonregulering gir økt risiko for beinskjørhet, overvekt, hjerte- og karsykdom samt type 2-diabetes hos personer med ryggmargsskade. Endret kroppssammensetning og inflammatorisk aktivitet kan medvirke til den økte forekomsten av hjerte- og karsykdom, diabetes og metabolsk syndrom, selv om andre sentrale risikofaktorer, som overvekt og forhøyet blodtrykk, kan mangle. Påviste hemostatiske og immunologiske forandringer kan så langt ikke dokumenteres å være av betydning for overhyppighet av tromboemboliske komplikasjoner, alvorlige infeksjoner eller spesielle kreftformer.

\section{Emil Kostovski}

emil.kostovski@sunnaas.no

Forskningsavdelingen

Sunnaas sykehus

1450 Nesoddtangen

\section{Per Ole Iversen}

Avdeling for ernæringsvitenskap

Institutt for medisinske basalfag

Universitetet i Oslo

og

Hematologisk avdeling

Oslo universitetssykehus, Ullevål

\section{Nils Hjeltnes}

Avdeling for ryggmargsskader og multitraumer Sunnaas sykehus

En ryggmargsskadet pasient pådrar seg som regel umiddelbart synlige lammelser, tap av sensibilitet og autonome forstyrrelser som rammer både de naturlige funksjoner (vannlating, tarmtømming og seksualfunksjon), blodtrykk og temperaturreguleringen. Akuttfasen preges av spinalt sjokk og den akutte traumeresponsen (1). Forventet levealder etter ryggmargsskade har økt markert gjennom de siste tiårene. Likevel finner man at ryggmargsskadede personer i Norge fortsatt har høyere dødelighet av bl.a. pneumoni $(16 \%)$ og urogenitale sykdommer $(13 \%)$, og de har en økt risiko for å utvikle hjerte- og karsykdom, type 2-diabetes og osteoporose (2). For å bedre leveutsiktene til personer med kronisk ryggmargsskade kreves økt forståelse og ytterligere kartlegging av årsakene til økt sykdomsrisiko. I denne artikkelen gir vi en oversikt over metabolske forandringer hos ryggmargsskadede personer i en kronisk og mer stabil metabolsk fase.

\section{Materiale og metode}

Artikkelen er basert på egen forskning, klinisk erfaring og ikke-systematiske søk i databasen PubMed.

\section{Forstyrrelser i beinmetabolismen}

De fleste pasienter med ryggmargsskade utvikler raskt osteopeni i de affiserte deler av kroppen og senere en alvorlig grad av osteoporose med høy risiko for frakturer. Leddnære bløtdelstraumer kan gi lokal heterotop ossifikasjon, selv mange år etter skaden (3).

Historisk har beinskjørhet etter ryggmargsskade blitt vurdert som en konsekvens av den fysiske inaktiviteten som skaden medfører. Men beintapet etter ryggmargsskade er ofte mer alvorlig enn det man finner etter ren immobilisering og er observert å være progredierende $\mathrm{i}$ over ti år etter skaden (4). Nevrologisk skade og hormonelle forandringer er således også funnet å være av patogenetisk betydning (5). Eksempler på hormonelle endringer som kan påvirke beinmassen, og som er observert hos personer med ryggmargsskade, er høye kortison-, insulin- og leptinnivåer samt lave kjønnshormon-, gonadotropin-, veksthormon- og IGFnivåer (5).

Innenfor en tidsperiode på ti uker etter skaden, og spesielt hos tidligere aktive unge gutter med komplette skader over Th5-nivået, ser man ofte forbigående hyperkalsemi, hyperkalsiuri og lave serumnivåer av parathyreoideahormon og $1,25(\mathrm{OH})_{2}$-vitamin D (6). Demineralisering av de lange knoklene i underekstremitetene dominerer. Mest affisert er distale femur og proksimale tibia. Demineralisering og beintap skjer som regel ikke, eller i langt mindre grad, kranialt for skadenivået og i ryggsøylen (7).

Ved diagnostisering av beintap anses Dual emission X-ray absorptiometry (DEXA) som gullstandardmetoden (8). I dag behandles beinskjørhet hos ryggmargsskadede med funksjonell elektrisk stimulering (FES) (fig 1), ståtrening og medikamentell behandling (kalsium, fosfat, vitamin D og bisfosfanater). Studier viser at funksjonell elektrisk stimulering øker beintettheten hos pasientene (9).

\section{Forstyrrelser i muskelmetabolismen}

Etter en ryggmargsskade utvikles lammelser med varierende grad av muskelsvinn under skadenivået. Omfanget av muskelatrofien

\section{Hovedbudskap}

- En ryggmargsskade kan gi autonome forstyrrelser og muskelhypotrofi samt endringer i lipid- og glukosemetabolismen

- Dette øker risikoen for overvekt, type 2-diabetes, hjerte- og karsykdom og osteoporose

- Endringer i hemostatiske mekanismer kan gi økt risiko for venøs tromboembolisme

- Vi anbefaler mosjon og årlige kontroller av kroppsvekt, blodsukker, blodtrykk samt blodlipider 
avhenger av om skaden rammer nedadgående nervebaner i ryggmargen (sentral skade), eller om den også rammer de motoriske forhorncellene (perifer skade). Perifer skade gir svær muskelatrofi og ses i lesjonsområdet der de tilhørende motornevronene er skadet, og etter skader av cauda equina. Muskler som har bevart normal nerveforsyning, vil derimot oftest være hypertrofiske som følge av mer bruk nå enn før skaden.

Den vanligvis lett spastiske lårmuskulaturen under skadenivået inneholder store mengder små type $2 \mathrm{~b}$-fibre, en del type 2afibre og så godt som ingen type 1-fibre, $i$ motsetning til funksjonsfrisk muskulatur der ulike fibertyper er mer jevnt fordelt (10).

I armmuskulaturen over skadenivået dominerer typisk store type 1-fibre med rikelige mengder aerobe enzymer (11). Disse forhold gjenspeiler med stor grad av sannsynlighet både mengden og typen arbeidsbelastning disse musklene utsettes for etter en ryggmargsskade $(9,11)$. I dag har man ingen rutinemessig behandling av muskelhypotrofi under skadenivået etter en ryggmargsskade. Beinsykling med funksjonell elektrisk stimulering av sentralt denervert muskulatur etter komplette skader og vektavlastende tredemølletrening etter inkomplette (ufullstendige) skader ser ut til å gi en «normalisering» av muskelfibersammensetningen (med endring fra type $2 b$ til type $2 a$, noen ganger også til type 1), muskelmassen og metabolske enzymer $(9,12-14)$.

\section{Forstyrrelser i lipid- og glukosemetabolismen}

Individer med ryggmargsskade har økt forekomst av hjerte- og karsykdom og type 2diabetes. Likevel tyder studier på at personer med kronisk ryggmargsskade har en lik eller lavere, men økende, dødelighet av hjerte- og karsykdom sammenliknet med funksjonsfriske (15-19). I en norsk retrospektiv studie utført av Lidal og medarbeidere, døde 18 av $\mathrm{i}$ alt 142 ryggmargskadede personer $(13 \%)$ av hjerte- og karsykdom i perioden 1961-2002, noe som er mindre enn for funksjonsfriske i den samme tidsperioden (2).

Nedsatt glukosetoleranse, hyperinsulinemi, type 2-diabetes, ugunstig blodlipidprofil (lav HDL-kolesterol, høy totalkolesterol, høye triglyserider og høy LDL-kolesterol) er hyppigere registrert hos ryggmargskadede personer enn hos funksjonsfriske. Avvikene fra referanseområdene er størst ved komplette cervikale skader (19). Det er videre funnet holdepunkter for økt kalsiuminnhold i karveggene, noe som kan tyde på økt arteriosklerotisk byrde (20). Ryggmargsskadede personer med normal kroppsmasseindeks (BMI) har ofte redusert muskel- og beinmasse og økt mengde kroppsfett sammenliknet med funksjonsfriske med tilsvarende BMI (9). Den reduserte muskelmassen bidrar til lavere insulinstimulert helkroppsopptak av blodglukose. Glukosebelastning viser derfor forhøyede nivåer av både insulin og blodglukose (19). In vitro finner man imidlertid normalt insulinstimulert glukoseopptak over muskelcellemembranen (10). Redusert muskelmasse, mer bindevev og fett i musklene og forandret vaskularisering innvirker trolig sammen på insulinets effekt, internalisering og nedbrytning og kan føre til hyperinsulinemi (10). Redusert muskelmasse sammen med endret sympatisk nerveaktivitet (etter ryggmargsskader over 5 . brystsegment), vil kunne redusere basalmetabolismen hos ryggmargsskadede personer med opptil $50 \%$ sammenliknet med funksjonsfriske (21). Forlenget halveringstid for en del aminosyrer i blodet og økte konsentrasjoner av triglyserider og LDL-kolesterol øker insulinproduksjonen, som kan gi ytterligere fettdeponering.

Trening, røykeslutt og diett har positiv effekt på lipidprofilen også hos ryggmargsskadede personer. Trening i rullestol og armøvelser tre ganger i uken reduserte LDL-kolesterol med $25 \%$ og økte HDL-kolesterol med $10 \%$ (22). Funksjonell elektrisk stimulering har vist å ha en gunstig påvirkning på glukosemetabolismen og blodlipidene (14). Daglig energiforbruk hos personer med tetraplegi er funnet å være signifikant redusert. Dette skyldes først og fremst redusert fysisk aktivitet, men også redusert hvilestoffskifte (23). For å redusere risikoen for hjerte- og karsykdom og forstyrrelser i lipid- og glukosemetabolismen anbefales pasientene vektreduksjon ved normal kroppsmasseindeks (BMI) sammenliknet med funksjonsfriske, tilsvarende $4-6 \mathrm{~kg}(5-10 \%)$ ved paraplegi, og 6-9 kg ved tetraplegi (10-15\%).

\section{Forstyrrelser i hemostasen}

Venøs tromboembolisme (dyp venetrombose og lungeemboli) er vanlige komplikasjoner etter ryggmargsskade. Høyest insidens av dyp venetrombose (38\%) og lungeembolier $(5 \%)$ er beskrevet de første tre månedene etter skade hos personer med paralytiske tilstander (24). Døgnvariasjonen, som man finner ved plasminogenaktivator-inhibitor 1 (PAI-1), TFPI (tissue factor pathway inhibitor), D-dimer, koagulasjonsfaktorene VII og VIII og protein $\mathrm{C}$ og protein $\mathrm{S}$ hos funksjonsfriske personer, kan være opphevet eller endret hos personer med ryggmargsskade (TFPI, fibrinspaltningsproduktet $\mathrm{F}_{1+2}$ og Ddimer) (25). Dette kan utgjøre en økt risiko for venøs tromboembolisme hos spinalskadede. I enkelte studier konkluderer man med at personer med ryggmargsskade rutinemessig bør screenes for venetrombose (26). Klinisk brukes ultralyd, CT, MR og biokjemiske markører (for eksempel D-dimer) kun diagnostisk. Profylaktisk behandling med elastiske strømper og kortkjedede hepariner i tre måneder etter skaden er kunnskapsbasert god praksis (27). Funksjonell elektrisk stimulering er i tillegg til å kompensere for normal muskelpumpe, vist å kunne normalisere fibrinolytisk aktivitet (28).

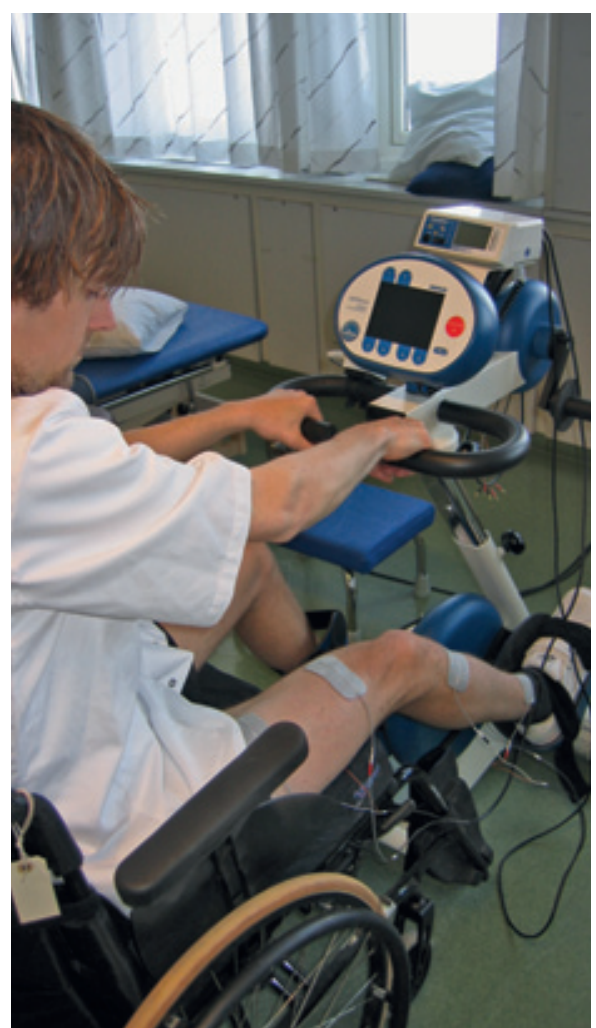

Figur 1 Arrangert bilde: Aktiv trening av «desentralisert» muskulatur ved hjelp av computerstyrt funksjonell elektrisk beinsykling

\section{Infeksjoner og kreft}

Det er observert nedsatt naturlig og adaptiv immunrespons og økte nivåer av cytokiner og interleukiner hos personer med ryggmargsskade $(29,30)$. De lave albuminnivåene i serum som registreres hos personer med høye ryggmargsskader i kronisk fase, oppfattes i dag som mulig indikator på en kronisk lett økt aktivitet $\mathrm{i}$ inflammatoriske signalkjeder. Funn av hemmet proliferasjon i alle hematopoetiske cellelinjer i desentralisert beinmarg, endret T-cellefunksjon og naturlig drepecellefunksjon kan redusere kroppens forsvar mot virus og «fremmede» celler $(31,32)$. Dette er interessante observasjoner i lys av at individer med spinalskade har økt risiko for å utvikle kreft i urinblære og muligens i tarm $(33,34)$. Nedsatt glukosetoleranse, insulinresistens og høye leptinnivåer er imidlertid også assosiert med nedsatt cellulær immunitet og kliniske infeksjoner (32). Forbedret immunitet er funnet etter gåtrening hos ryggmargsskadede personer (35).

\section{Infertilitet og hypogonadisme}

Det er påvist både redusert fertilitet og svekket ereksjons- og ejakulasjonsevne hos menn med ryggmargsskader $(36,37)$. Studier har vist økt antall spermier med unormal morfologi og nedsatt bevegelighet $(36,38)$. Ovarialfunksjonen er ikke affisert i kjent grad. I eget arbeid har vi funnet opptil $30 \%$ lavere plasmanivåer av testosteron, luteiniserende hormon (LH) og follikkelstimulerende hormon 
(FSH) hos seks mannlige tetraplegikere sammenliknet med åtte funksjonsfriske (39). I andre studier er det imidlertid vist både høyere, lavere og normale plasmanivåer av testosteron, LH og FSH hos ryggmargsskadede menn (40). Ryggmargsskadede menn kan gjøre sin partner gravid på naturlig måte, men de fleste må enten bruke spesialinstrumenter for vibrasjonsstimulering eller elektrisk stimulering for å fremkalle ejakulat, som kan benyttes til in vitro-fertilisering. Dersom dette heller ikke lykkes, kan spermier hentes mikrokirurgisk fra epididymis til intracytoplasmatisk spermieinjeksjon.

\section{Diskusjon}

I den kroniske fasen etter ryggmargsskade finner man økt forekomst av hjerte- og karsykdom og type 2-diabetes. Det er nærliggende å knytte disse funn til samtidig påvisning av muskelhypotrofi og økt fettmasse (41), da dette danner grunnlag for nedsatt glukosetoleranse, insulinresistens, endring av fetthormoner og en ugunstig blodlipidprofil. Immobiliseringen sammen med nevrogene og hormonelle endringer bidrar sterkt til utviklingen av alvorlig osteoporose. Det er ennå ikke funnet klare sammenhenger mellom den økte forekomsten av venøs tromboembolisme og endringer $\mathrm{i}$ de hemostatiske mekanismene. Svekket immunforsvar og reduserte blodnivåer av androgene hormoner er i noen studier sett i sammenheng med henholdsvis hyppigere infeksjoner eller kreft og redusert fertilitet (42) (fig 2).

De nevnte forandringer kan fremfor alt relateres til langvarig ekstrem fysisk inaktivitet som følge av de fysiske lammelsene og til reguleringsforstyrrelser i det autonome nervesystemet. Det er naturlig å knytte sammen påviste risikofaktorer og økt hyppighet av hjerte- og karsykdom og type 2-diabetes, selv om den kausale sammenhengen ikke er dokumentert i prospektive langtidsstudier hos denne gruppen. Personer med ryggmargsskader over 6 . torakale segment fremstår heller ikke med det komplette bildet av metabolsk syndrom, da blodtrykket ofte er lavt i sittende stilling, og de er utsatt for ortostatisk hypotensjon og blodtrykksfall i forbindelse med fysiske anstrengelser som følge av redusert sympatikustonus. Personer med skade under 6 . torakale segment har derimot en tendens til hypertensjon på lang sikt, men har ikke samme risiko for type 2diabetes som de med høyere skadenivåer.

Det eksisterer ikke egne retningslinjer for individuell primærforebygging og behandling av hjerte- og karsykdom og diabetes hos ryggmargskadede personer, selv om dette diskuteres (41). Likevel anbefales årlig sjekk av fastende blodsukker og blodlipider. Ved måling av blodtrykk hos personer med autonom dysrefleksi, bør ambulatoriske

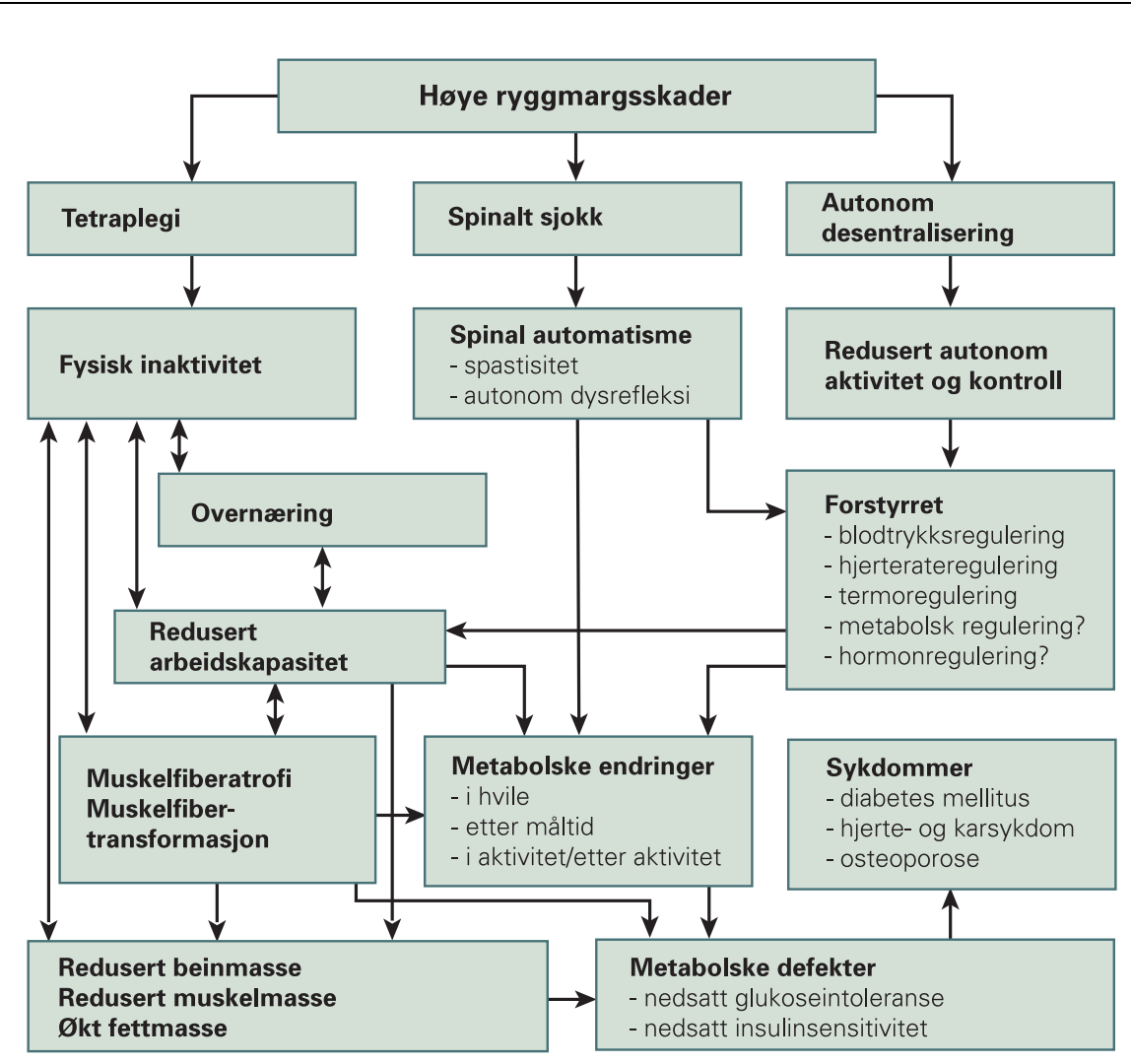

Figur 2 Skjematisk illustrasjon av nevrogene, kardiovaskulære, metabolske og funksjonelle konsekvenser av en cervikal ryggmargsskade. Piler indikerer både konsekvenser og interaksjoner. Følgene av fysisk inaktivitet gjelder i mer eller mindre grad for alle ryggmargsskadede personer, mens man må ha et skadenivå over Th1 for at alle følger av sympatisk «desentralisering» skal gjelde (42)

langtidsmålinger brukes. Dyptgripende endringer i kroppssammensetningen gjør at BMI ikke er egnet til å bedømme overvekt etter ryggmargsskade uten at en ny korrigert indeks blir tilgjengelig.

Den medikamentelle behandlingen av osteoporose hos ryggmargskadede personer skiller seg ikke ut fra den som gis til funksjonsfriske. Imidlertid har funksjonell elektrisk stimulering med sykling gitt positive resultater selv om dette fremdeles er relativt lite utbredt, særlig på grunn av kostnadene knyttet til selve instrumentet og liten brukervennlighet i hjemmet. Ståtrening og mobilisering brukes i dag i rehabilitering og i hjemmet, men dokumentasjon på at denne intervensjonen vedlikeholder beintettheten etter ryggmargsskade mangler. Det er en stor utfordring å reversere de katabole prosessene etter en ryggmargsskade. Man kan prøve å «kompensere» gjennom funksjonell elektrisk stimulering eller ved ekstra mye trening av den funksjonsfriske delen av kroppen. Det siste medfører imidlertid økt risiko for overbelastningsproblemer. Den sterkt reduserte muskelmassen medfører at serumkreatinin er lavt, og en «normal» s-kreatinin hos en ryggmargsskadet person med omfattende muskelhypotrofi kan indikere begynnende nyresvikt. Risiko for nye tromboemboliske komplikasjoner er økt i forbindelse med sengeleie pga. interkurrente sykdommer også i kronisk fase. Ved slike anledninger anbefales forebyggende antikoagulasjonsbehandling.

Ennå vet vi lite om årsaker til en mulig immunsuppresjon etter ryggmargsskade. Forstyrret autonom regulering av mukøst og lymfoid vev og forandret signalering til immunregulerende nevroner i sentralnervesystemet bidrar sannsynligvis (43). Urinveisinfeksjoner bidrar til økt morbiditet og mortalitet etter ryggmargsskade $(2,16,44)$. Dette skyldes først og fremst skadens forstyrrelse av den nervøse reguleringen av nedre urinveier som medfører resturin og som nødvendiggjør bruk av urinveiskatetre. Residiverende urinveisinfeksjoner øker risikoen for amyloide avleiringer og nyresvikt (45).

De viktigste predisponerende faktorer for lungesykdommer (pneumonier og atelektaser) og lungedød hos personer med ryggmargsskade er nedsatt hostekraft, økt bronkokonstriksjon og mukusproduksjon pga. uhemmet parasympatisk aktivitet $(1,46)$. Ny informasjon om immunforsvaret hos ryggmargsskadede individer har til nå ikke fått terapeutiske konsekvenser, selv om man i praksis er mindre restriktiv med bruk av antibiotika mot luftveis- og urinveisinfeksjoner.

Det er fortsatt manglende kunnskaper om hvilke hormonelle endringer en ryggmargsskade kan føre til og hvilke konsekvenser disse har for fertilitet og metabolisme. Medikamenter, det å sitte stille lenge, gjennomsnittlig forhøyet skrotal temperatur og stress 
er foreslått som medvirkende årsaker til redusert fertilitet (37). Det eksisterer ingen spesielle prosedyrer for å forebygge redusert fertilitet utover generelle tiltak som å forebygge urinveisinfeksjoner (inklusive epididymitt) og andre medisinske komplikasjoner som svekker almenntilstanden.

\section{Konklusjon}

Gjennomsnittlig forventet levetid øker stadig etter ryggmargsskade. Likevel er den gjennomsnittlige livslengden fremdeles redusert og komorbiditeten økt sammenliknet med funksjonsfriske (2). Flere studier har over tid gitt oss økt innsikt i bakenforliggende metabolske forandringer i den kronisk fasen. Dette øker mulighetene for både å kunne forebygge komplikasjoner og å gi bedre behandling når sykdommer inntreffer. Da det ikke vil være aktuelt å kunne kurere en ryggmargsskade i overskuelig fremtid, må ny kunnskap om metabolske og morfologiske forhold ut til fastlegen og den funksjonshemmede for å bidra til at helsen og behovene ivaretas bedre enn tidligere.

\section{Oppgitte interessekonflikter: Ingen}

\section{Litteratur}

1. Garstang SV, Miller-Smith SA. Autonomic nervous system dysfunction after spinal cord injury. Phys Med Rehabil Clin N Am 2007: 18: 275-80.

2. Lidal IB, Snekkevik H, Aamodt G et al. Mortality after spinal cord injury in Norway. J Rehabil Med 2007; 39: 145-51.

3. Cipriano CA, Pill SG, Keenan MA. Heterotopic ossification following traumatic brain injury and spinal cord injury. J Am Acad Orthop Surg 2009; 17: 689-97

4. Bauman WA, Spungen AM, Wang J et al. Continuous loss of bone during chronic immobilization: a monozygotic twin study. Osteoporos Int 1999: 10: $123-7$

5. Jiang SD, Dai LY, Jiang LS. Osteoporosis after spinal cord injury. Osteoporos Int 2006; 17: 180-92.

6. Bauman WA, Morrison NG, Spungen AM. Vitamin $D$ replacement therapy in persons with spinal cord injury. J Spinal Cord Med 2005; 28: 203-7.

7. Jiang SD, Jiang LS, Dai LY. Mechanisms of osteoporosis in spinal cord injury. Clin Endocrinol (Oxf) 2006: 65: 555-65.

8. Syed Z, Khan A. Bone densitometry: applications and limitations. J Obstet Gynaecol Can 2002; 24 : 476-84

9. Hjeltnes N, Aksnes AK, Birkeland Kl et al. Improved body composition after 8 wk of electrically stimulated leg cycling in tetraplegic patients. Am J Physiol 1997; 273: 1072-9.

10. Aksnes AK, Hjeltnes N. Wahlstrom EO et al. Intact glucose transport in morphologically altered denervated skeletal muscle from quadriplegic patients. Am J Physiol 1996; 271: 593-600.
11. Schantz P, Sjöberg B, Widebeck AM et al. Skeletal muscle of trained and untrained paraplegics and tetraplegics. Acta Physiol Scand 1997; 161: 31-9.

12. Stewart BG, Tarnopolsky MA, Hicks AL et al. Treadmill training-induced adaptations in muscle phenotype in persons with incomplete spinal cord injury. Muscle Nerve 2004; 30: 61-8.

13. Phillips SM, Stewart BG, Mahoney DJ et al. Bodyweight-support treadmill training improves blood glucose regulation in persons with incomplete spinal cord injury. J Appl Physiol 2004; 97: 716-24.

14. Mahoney ET, Bickel CS, Elder $\mathrm{C}$ et al. Changes in skeletal muscle size and glucose tolerance with electrically stimulated resistance training in subjects with chronic spinal cord injury. Arch Phys Med Rehabil 2005; 86: 1502-4

15. Lloyd-Jones D, Adams R, Carnethon M et al. Heart disease and stroke statistics - 2009 update: a report from the American Heart Association Statistics Committee and Stroke Statistics Subcommittee. Circulation 2009; 119: 480-6.

16. Frankel HL, Coll JR, Charlifue SW et al. Long-term survival in spinal cord injury: a fifty year investigation Spinal Cord 1998: 36:266-74.

7. Whiteneck GG, Charlifue SW, Frankel HL et al. Mortality, morbidity, and psychosocial outcomes of persons spinal cord injured more than 20 years ago. Paraplegia 1992: 30: 617-30.

18. Lavis TD, Scelza WM, Bockenek WL. Cardiovascular health and fitness in persons with spinal cord injury. Phys Med Rehabil Clin N Am 2007; 18: $317-31$

19. Bauman WA, Spungen AM. Carbohydrate and lipid metabolism in chronic spinal cord injury. J Spinal Cord Med 2001; 24: 266-77.

20. Orakzai SH, Orakzai RH, Ahmadi N et al. Measure ment of coronary artery calcification by electron beam computerized tomography in persons with chronic spinal cord injury: evidence for increased atherosclerotic burden. Spinal Cord 2007; 45: $775-9$.

21. Aksnes AK, Brundin T. Hjeltnes $\mathrm{N}$ et al. Mealinduced rise in resting energy expenditure in patients with complete cervical spinal cord lesions. Paraplegia 1993; 31: 462-72.

22. Nash MS, Jacobs PL, Mendez AJ et al. Circuit resistance training improves the atherogenic lipid profiles of persons with chronic paraplegia. J Spinal Cord Med 2001; 24: 2-9.

23. Buchholz AC, Pencharz PB. Energy expenditure in chronic spinal cord injury. Curr Opin Clin Nutr Metab Care 2004: 7: 635-9.

24. Anderson FA jr., Spencer FA. Risk factors for venous thromboembolism. Circulation 2003; 107: $19-6$

25. Iversen PO, Groot PD, Hjeltnes N et al. Impaired circadian variations of haemostatic and fibrinolytic parameters in tetraplegia. Br J Haematol 2002; 119: $1011-6$.

26. Furlan JC, Fehlings MG. Role of screening tests for deep venous thrombosis in asymptomatic adults with acute spinal cord injury: an evidencebased analysis. Spine 2007; 32: 1908-16.

27. Geerts WH, Bergqvist D, Pineo GF et al. Prevention of venous thromboembolism: American College of Chest Physicians Evidence-Based Clinical Practice Guidelines (8th Edition). Chest 2008; 133: 381-453S.

28. Katz RT, Green D, Sullivan T et al. Functional electric stimulation to enhance systemic fibrinolytic activity in spinal cord injury patients. Arch Phys Med Rehabil 1987; 68: 423-6.
29. Nash MS. Known and plausible modulators of depressed immune functions following spinal cord injuries. J Spinal Cord Med 2000; 23: 111-20.

30. Davies AL, Hayes KC, Dekaban GA. Clinical correlates of elevated serum concentrations of cytokines and autoantibodies in patients with spinal cord injury. Arch Phys Med Rehabil 2007; 88: 1384-93.

31. Iversen PO, Hjeltnes N, Holm B et al. Depressed immunity and impaired proliferation of hematopoietic progenitor cells in patients with complete spinal cord injury. Blood 2000; 96: 2081-3.

32. Frost FS, Pien LC. The immune system and inflammatory response in persons with SCl. I: Lin VW, Cardenas DD, red. Spinal cord medicine: principles and practice. New York, NY: Demos Medical Publishing, 2002: 213-21.

33. Subramonian K, Cartwright RA, Harnden P et al. Bladder cancer in patients with spinal cord injuries. BJU Int 2004: 93: 739-43.

34. Slattery ML, Edwards S, Curtin K et al. Physical activity and colorectal cancer. Am J Epidemiol 2003; 158: 214-24.

35. Kawashima N, Nakazawa K, Ishii N et al. Potentia impact of orthotic gait exercise on natural killer cell activities in thoracic level of spinal cordinjured patients. Spinal Cord 2004; 42: 420-4.

36. Stien R. Seksuell dysfunksjon hos ryggmargsskadede menn. Tidsskr Nor Legeforen 2008; 128: 453-6.

37. Elliot S. Sexual dysfuntion and infertility in men with spinal cord disorders. Lin VW, Cardenas DD, red. Spinal cord medicine: principles and practice. New York, NY: Demos Medical Publishing, 2002 349-67.

38. Naderi AR, Safarinejad MR. Endocrine profiles and semen quality in spinal cord injured men. Clin Endocrinol (Oxf) 2003; 58: 177-84.

39. Kostovski E, Iversen PO, Birkeland K et al. Decreased levels of testosterone and gonadotrophins in men with long-standing tetraplegia. Spinal Cord 2008; 46: 559-64

40. Huang TS, Wang YH, Chen SY. The relation of serum leptin to body mass index and to serum cortisol in men with spinal cord injury. Arch Phys Med Rehabil 2000; 81: 1582-6.

41. Bauman WA, Spungen AM. Coronary heart disease in individuals with spinal cord injury: assessment of risk factors. Spinal Cord 2008; 46: 466-76.

42. Hjeltnes N. Physical exercise and electrical stimulation in the management of metabolic, cardiovascular and skeletal-muscle alterations in people with tetraplegia. Doktorgradsavhandling. Stockholm: Karolinska sjukhuset, 1998: 12.

43. Bellinger DL, Millar BA, Perez S et al. Sympathetic modulation of immunity: relevance to disease. Cell Immunol 2008; 252: 27-56.

44. Krause JS, Carter RE, Pickelsimer EE et al. A prospective study of health and risk of mortality after spinal cord injury. Arch Phys Med Rehabil 2008. 89: $1482-91$.

45. Barton $\mathrm{CH}$, Vaziri ND, Gordon S et al. Renal pathology in end-stage renal disease associated with paraplegia. Paraplegia 1984; 22: $31-41$

46. Garshick E, Kelley A, Cohen SA et al. A prospective assessment of mortality in chronic spinal cord injury. Spinal Cord 2005; 43: 408-16.

Manuskriptet ble mottatt 12.1. 2009 og godkjent 15.4. 2010. Medisinsk redaktør Trine B. Haugen. 